\title{
Lateral Offsets on Surveyed Cultural Features Resulting from the 1999 İzmit and Düzce Earthquakes, Turkey
}

\author{
by Thomas K. Rockwell, Scott Lindvall, Tim Dawson, Rob Langridge, \\ William Lettis, and Yann Klinger
}

\begin{abstract}
Surveys of offset linear cultural features that cross the surface ruptures of the 17 August and 12 November 1999 earthquakes on the North Anatolian fault in Turkey yield slip values as large as or larger than those recorded by near-field measurements in the same areas immediately after the earthquake. Using long, linear alignments of trees, fence lines, walls, and canals, we demonstrate as much as a $2-m$ increase in observed slip over the initial field measurements. On an average, we observed about $15 \%$ of the total lateral slip as off-fault deformation, with values ranging from $0 \%$ to $40 \%$ of the total slip. Part of this lateral deformation is accommodated by bending or drag in a zone as much as $30 \mathrm{~m}$ in width, although usually the zone varies between 5 and $20 \mathrm{~m}$ in width. This supports the idea that substantial nonbrittle, off-fault deformation is associated with ruptures in areas of alluvial fill. Alternatively, there may have been substantial afterslip, although none has been recognized on postearthquake repaired structures. Our observations suggest that postearthquake measurements of fault slip, using tape measures on offset geomorphic features, may underestimate the actual amount of slip in that event, where the nonlinearity of the offset feature does not allow recognition of the warping.

Surveys of multiple tree lines within groves of poplar trees, planted in straight lines across the fault prior to the earthquake, show surprisingly large lateral variations. In one grove, slip increases by nearly $1.8 \mathrm{~m}$, or $35 \%$ of the maximum measured value, over a lateral distance of nearly $100 \mathrm{~m}$. This and other observations along the 1999 ruptures suggest that the lateral variability of slip observed from displaced geomorphic features in many earthquakes of the past may represent a combination of (1) actual differences in slip at the surface and (2) the difficulty in recognizing distributed nonbrittle deformation.
\end{abstract}

\section{Introduction}

Determination of surface slip during large earthquakes is important for understanding the physical parameters involved in the rupture process and in forecasting the likely size of future earthquakes on faults that have not yet produced large historical earthquakes. The slip distribution along many recent strike-slip surface ruptures has been determined by detailed mapping and near-field measurements of slip (tape measure) in the field (Sharp, 1982; Hudnut et al., 1989; Sharp et al., 1989; Sieh et al., 1993; Zachariasen and Sieh, 1995; Hector Mine Working Group, 2000). These types of observations have been used to estimate the average and maximum displacement for a given rupture length in future large earthquakes (Wells and Coppersmith, 1994). However, in most cases, slip was measured using offset geomorphic features, such as small channels and channel margins, channel deposits, including bars and swales, small ridgelines, tire tracks, edges of small pull-aparts, and other curvilinear features, that do not accurately record deformation outside of a narrow zone along the main rupture. Furthermore, distributed slip across a broad zone of fracturing is difficult to measure with small geomorphic features. Thus, in nearly all cases, these displaced features record primarily the very near-field displacement along the primary rupture trace, and there are few data on the breadth of distributed shearing.

Significant variations in lateral slip along fault strike have also been noted on various scales for most strike-slip fault ruptures (e.g., Clark, 1972; Zachariasen and Sieh, 1995; McGill and Rubin, 1999; Langridge et al., 2002). However, what has not been clear is how much of this variability is due to misrecognition of slip from bending or distributed slip and other deformations, rather than actual differences in 
surface slip. Some workers have concluded that measurements of a factor of $20 \%-100 \%$ in slip variability over distances of tens to hundreds of meters are not uncommon, after studying the lateral variability of slip based on offset geomorphic features after the Landers earthquake (McGill and Rubin, 1999). This has implications for discriminating between one or multiple discrete events or estimating the size of past earthquakes (Sieh, 1978; Rockwell and Pinault, 1986; Lindvall et al., 1989; McGill and Sieh, 1991; Weldon et al., 1996; McGill and Rubin, 1999) using displaced deposits in trenches or offset geomorphic features.

After the M 7.4 İzmit earthquake of 17 August 1999 and the $M 7.1$ Düzce earthquake of 12 November 1999, teams of geologists mapped the surface ruptures and measured hundreds of offset geomorphic and cultural features in order to resolve slip distribution (Figs. 1 and 2) (Akyuz et al., 2000; Barka et al., 2000; Hartleb et al., 2002; Langridge et al., 2002). Lateral variability was again observed (Fig. 2), but this time, a number of these observations were based on projecting long, linear cultural features into and across the fault zone. The Turkey earthquakes occurred in an area of very long cultural development, and numerous cultural features were constructed across the strands of the North Anatolian fault. Better yet, several poplar tree (Kavak) groves, which consist of very long, linear, parallel rows of trees, straddle the fault zone. Thus, there is the potential for assessing slip from multiple, closely spaced alignment arrays along the 1999 surface ruptures.

After the November event, we measured slip on 33 features at 11 sites along these two surface ruptures (Fig. 1) by surveying long alignments of trees, fences, walls, and canals with a total station. We surveyed these offset features in order to (1) evaluate previous field measurements taken after each of the earthquakes, (2) accurately determine slip at a number of points along the ruptures, and (3) test for far-field deformation and slip variability. This article presents and summarizes the results of these surveys and discusses the implications of our observations on previously determined slip values for other earthquakes, where geomorphic features were principally used for determining slip.

\section{Methodology}

The majority of the fieldwork for this project was performed during the period from 18 to 28 November 1999 , soon after the 12 November Düzce earthquake. Additional surveying was performed during July 2000 to capture an additional site and to expand the number of trees surveyed at Arifiye (site 9), where maximum slip was measured. We first scouted out potential survey sites and chose 10 areas to make detailed surveys of displaced, originally straight, cultural features that cross the fault at a high angle (Table 1). Some of the surveyed sites on the August İzmit earthquake rupture directly correspond to features that were measured after that earthquake.

We surveyed three sites along the November Düzce rupture (sites 1-3) and eight sites along the August İzmit rupture (sites 4-11) for a total of 11 survey sites, some of which included multiple features (Table 1 and Fig. 1). These surveys were designed primarily to measure the total deformation and to discriminate between near-field slip on the principal fault zone, slip on secondary fault strands, and nonbrittle far-field slip. In this study, we define total deformation as the total observed dextral slip based on the reconstruction of originally linear features and include the bending or warping measured up to several tens of meters away from the fault (Fig. 3). Near-field slip is defined as lateral offset measured at the primary surface rupture itself, which usually occurs within a zone a few meters wide. We define far-field slip as the total deformation minus the sum of near-field slip and the slip on discrete secondary fault strands. In some areas, far-field slip was substantial, whereas in others, it was not. In all cases, quantification of the far-field deformation is important, as this may be a major cause for undermeasurement of slip in some earthquakes. The long, linear cultural features that we surveyed afforded an excellent assessment of far-field deformation measured over many tens of meters away from the primary rupture.

For some sites where the rupture traverses poplar

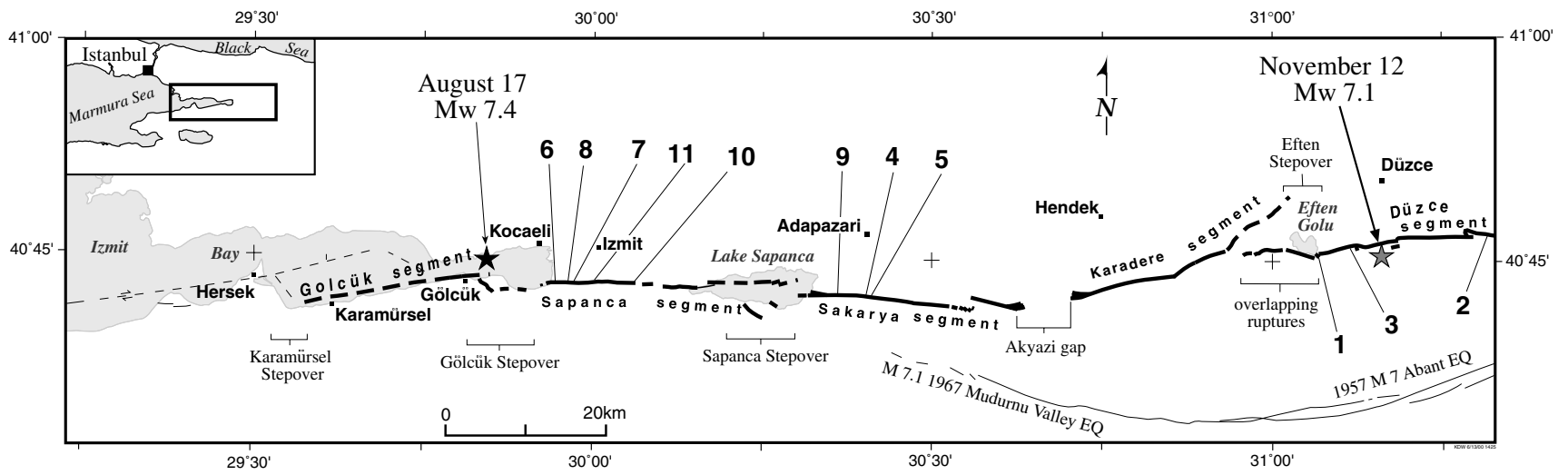

Figure 1. Map of the 1999 İzmit and Düzce surface ruptures. Note the locations of our 11 survey sites of offset cultural features and tree groves. 

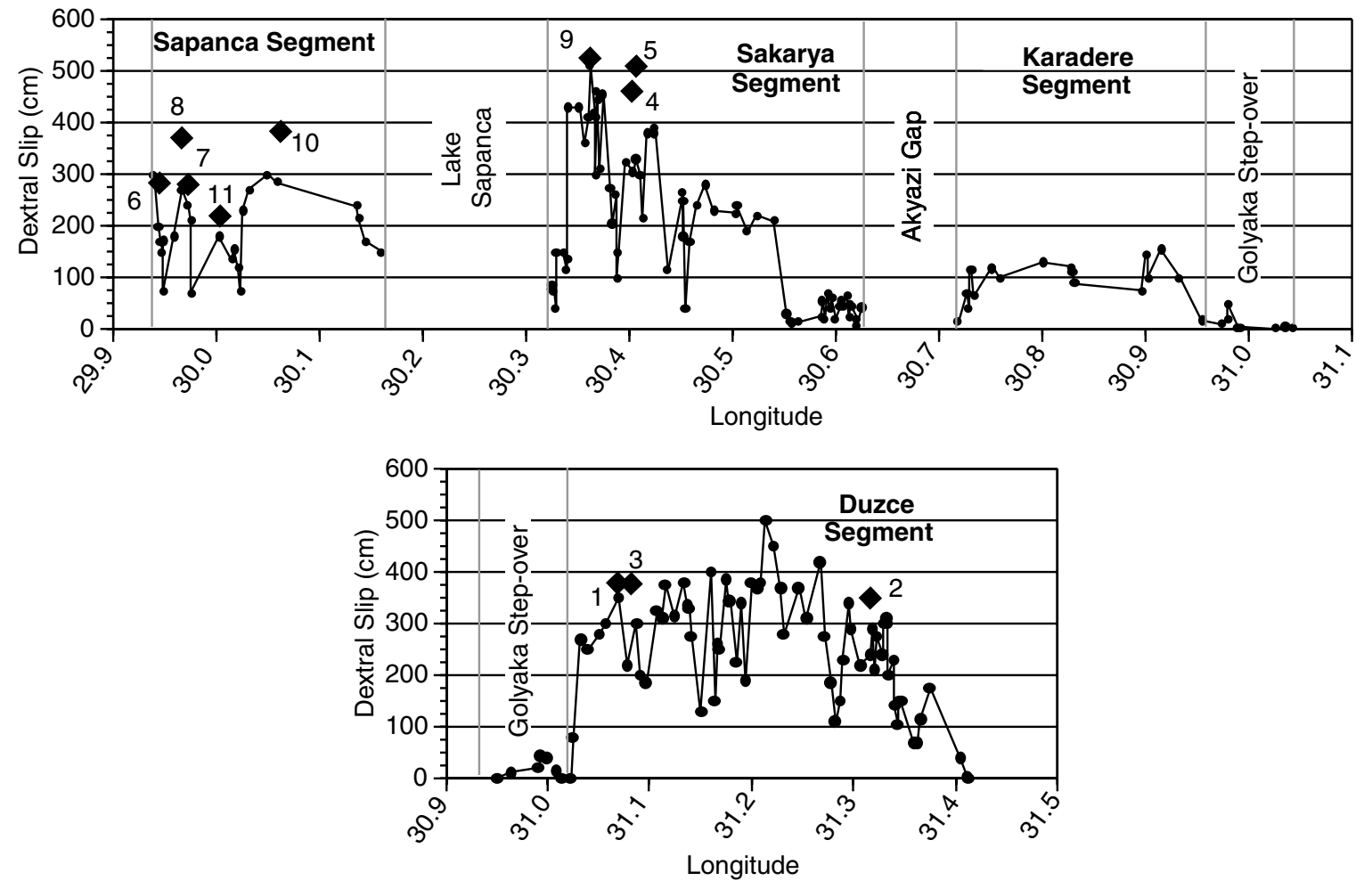

Figure 2. Slip distribution along a portion of the (a) 17 August earthquake rupture east of İzmit Bay and the (b) 12 November Düzce rupture (bottom) showing our survey results (diamonds with corresponding site numbers) superposed on the slip distribution curve based on field measurements made by tape measure (from Akyuz et al., 2000; Barka et al., 2000).

Table 1

Survey Sites along the İzmit and Düzce Surface Ruptures

\begin{tabular}{|c|c|c|c|c|c|c|c|}
\hline $\begin{array}{l}\text { Survey } \\
\text { Number }\end{array}$ & $\begin{array}{l}\text { Earthquake } \\
\text { Rupture }\end{array}$ & $\begin{array}{c}\text { Fault } \\
\text { Segment }\end{array}$ & $\begin{array}{l}\text { Date of Survey } \\
(\mathrm{mm} / \mathrm{dd} / \mathrm{yy})\end{array}$ & Surveyed Offset Feature(s) & General Location & $\begin{array}{l}\text { Latitude } \\
\quad\left({ }^{\circ}\right)\end{array}$ & $\begin{array}{l}\text { Longitude } \\
\quad\left({ }^{\circ}\right)\end{array}$ \\
\hline 6 & 17 August & Sapanca & $11 / 25 / 99$ & Margins of concrete flood control channel & Near İzmit Bay & 40.7208 & 29.9464 \\
\hline 8 & 17 August & Sapanca & $11 / 25 / 99$ & Fence with wooden posts & Near İzmit Bay & 40.7208 & 29.9667 \\
\hline 7 & 17 August & Sapanca & $11 / 25 / 99$ & Wall at razed apartment complex & Near İzmit Bay & 40.7213 & 29.9730 \\
\hline 11 & 17 August & Sapanca & $07 / 20 / 00$ & Trees from a Kavak grove ( 3 rows) & Tepatarla & 40.7200 & 30.0000 \\
\hline 10 & 17 August & Sapanca & $11 / 26 / 99$ & Kavak stumps (2 rows) & Tepatarla & 40.7203 & 30.0617 \\
\hline $9 \mathrm{a}$ & 17 August & Sakarya & $11 / 26 / 99$ & Trees from large Kavak grove ( 4 rows) & Arifiye & 40.7097 & 30.3619 \\
\hline $9 b$ & 17 August & Sakarya & $07 / 21 / 00$ & Trees from large Kavak grove ( 8 more rows) & Arifiye & 40.7097 & 30.3619 \\
\hline 4 & 17 August & Sakarya & $11 / 24 / 99$ & Kavak trees and stumps ( 7 rows) & Near Sakarya River. & 40.7080 & 30.4034 \\
\hline 5 & 17 August & Sakarya & $11 / 24 / 99$ & Kavak trees along river ( 4 rows) & Sakarya River & 40.7072 & 30.4077 \\
\hline 1 & 12 November & Düzce & $11 / 22 / 99$ & Walls at 'Forest Service' station & Near Eften Golu & 40.7558 & 31.0678 \\
\hline 3 & 12 November & Düzce & $11 / 23 / 99$ & Elevated concrete flume & Eften Golu & 40.7612 & 31.0875 \\
\hline 2 & 12 November & Düzce & $11 / 23 / 99$ & Fence with concrete posts in orchard & Kaynasli & 40.7755 & 31.3185 \\
\hline
\end{tabular}

groves, multiple tree lines were measured to assess slip variability and repeatability of measurements along the rupture. We surveyed all the tree lines in the grove where maximum slip was measured (site 9, Fig. 1) because slip measurements taken after the İzmit earthquake (Barka et al., 2000; Langridge et al., 2002) exhibited substantial variability. In all, three sites include a matrix of trees and stumps that cross the fault where variability can be assessed.

For the survey, we used a lightweight, highly portable
Criterion 300 total station and a Wild TC 2000 total station, both utilizing a retroflective prism. We tested both horizontal and vertical accuracies for the Criterion 300 and found the horizontal errors to be of the order of $2 \mathrm{~cm}$, whereas vertical accuracy and precision was only about $\pm 10-15 \mathrm{~cm}$. However, errors appear to be systematic in a positive or negative direction, depending on whether it is shot slightly up or down; therefore, the relative error is less. Both horizontal and vertical accuracies for TC 2000 are of the order of a few 


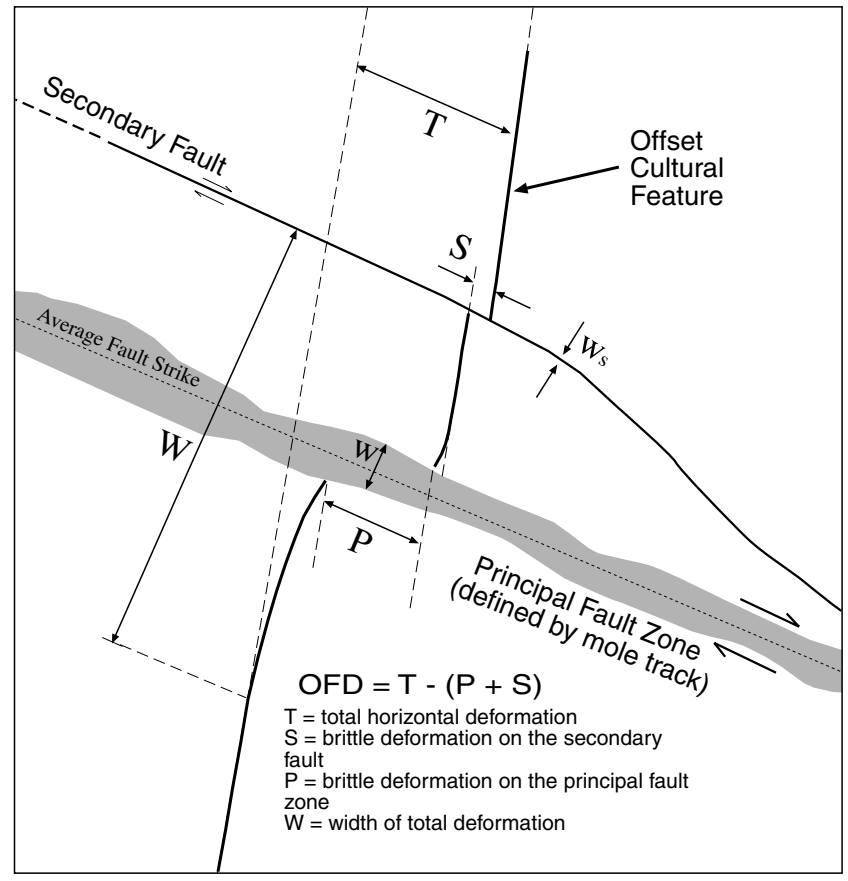

Figure 3. Schematic figure showing offset long, linear cultural feature and the various definitions of slip, width of deformation, and off-fault deformation (OFD) that are listed in Table 2.

millimeters. For assessing horizontal slip, we accept these errors to be within a reasonable margin, as measured strike slip from the earthquakes was over two orders of magnitude greater. Furthermore, uncertainties for our slip estimates due to all error sources range up to $\pm 115 \mathrm{~cm}$, although many were less than $20 \mathrm{~cm}$.

The data were input into spreadsheets and plotted using graphing software. To measure slip, we plotted the survey data on a 36-inch-wide color plotter with a scale of 1:100 (Figs. 3-12). Thus, we could accurately measure to better than $\pm 10 \mathrm{~cm}$ (1 $\mathrm{mm}$ on the 1:100 scale). We reconstructed the originally straight alignment features, assuming that they had similar trends on each side of the fault prior to the earthquake. We found substantial uncertainties in many cases, which we attempted to estimate (Table 2). Uncertainties are the result of several factors, some of which include (1) variability in the original straightness of the offset feature, (2) earthquake-related fling or toppling of concrete structures that affected our reconstructions, (3) judgment on where the survey rod was placed at the time of the survey, (4) estimate of the fault strike, (5) judgment in discriminating between off-fault warping and original nonlinearity of the feature, and (6) errors inherent in the analysis and how we reconstructed the linear features.

The aligned poplar trees were apparently planted in remarkably straight lines, based on their current linearity away from the fault. Nevertheless, in a few cases, individual trees appear to have been planted as much as $20 \mathrm{~cm}$ out of alignment. For each tree line, we attempted to place an estimate of potential error on the reconstruction, based on the straightness of the trees. Similarly, there is some judgment required in reconstructing each alignment that may result in some uncertainty. We attempted different reconstructions to test potential error and made estimates of these uncertainties. In the cases of concrete structures, some error may have been introduced by rotations of the concrete blocks themselves or fling of the structures within the fault zone, so we attempted to quantify this as well. We combined each of these possible sources of error and assigned an error term to each measurement. Uncertainties are as small as $\pm 15 \mathrm{~cm}$, where the feature exhibits an exceptional linearity and as much as 115 $\mathrm{cm}$, where the zone of deformation appeared very broad, and our survey may not have completely encompassed the total width of deformation. In the discussion given subsequently, we present the best estimates of our slip measurements and request the reader to refer to Table 2 for estimates on the errors.

\section{Description of Sites and Estimates of Slip}

The 11 survey sites were sequentially numbered 1 through 11 in the order in which they were surveyed. To aid in the discussion of each site, we begin with the westernmost site on the 17 August rupture and progress eastward to the 12 November rupture, rather than by site number. Along the 17 August rupture, we surveyed five sites $(6,8,7,11$, and $10)$ on the Sapanca segment and three sites $(9,4$, and 5) on the Sakarya segment (Fig. 1). Of the eight sites on the August rupture, six sites $(6,11,10,9,4$, and 5) involved surveys of multiple linear features. We did not survey any offsets along either the Golcuk or Karadere segments. Three survey sites $(1,3$, and 2) are located on the Düzce segment of the 12 November rupture (Fig. 1).

\section{Sapanca Segment: 17 August Rupture}

Site 6, located near İzmit Bay, is the westernmost site surveyed and consisted of an offset flood control channel constructed with rock and concrete (Fig. 4) (figure 14 of U.S. Geological Survey, 2000). We surveyed the top edge of the walls of the channel over an aperture of about $120 \mathrm{~m}$ centered on the primary fault zone, which is about 5-6 m wide. Warping of the walls is noted for a distance of 5-15 m out from the main fault, indicating a deformation zone width of about 10-25 m. Brittle slip across the main fault zone for these two walls is nearly identical at about $1.5 \mathrm{~m}$, whereas total slip, including warping, is estimated at $2.1 \mathrm{~m}$ for the western wall and $2.05 \mathrm{~m}$ for the eastern wall. Thus, this observation demonstrates that our surveying is reproducible. A secondary strand is located about $70 \mathrm{~m}$ south of the primary fault and expresses an additional $0.75 \mathrm{~m}$ of dextral slip. Thus, the total dextral deformation across this channel is about $2.8 \mathrm{~m}$.

Site 8 consists of an offset barbed-wire fence constructed with wooden fence posts, which exhibits an exceptional linearity on both sides of the fault. The base of each fence 


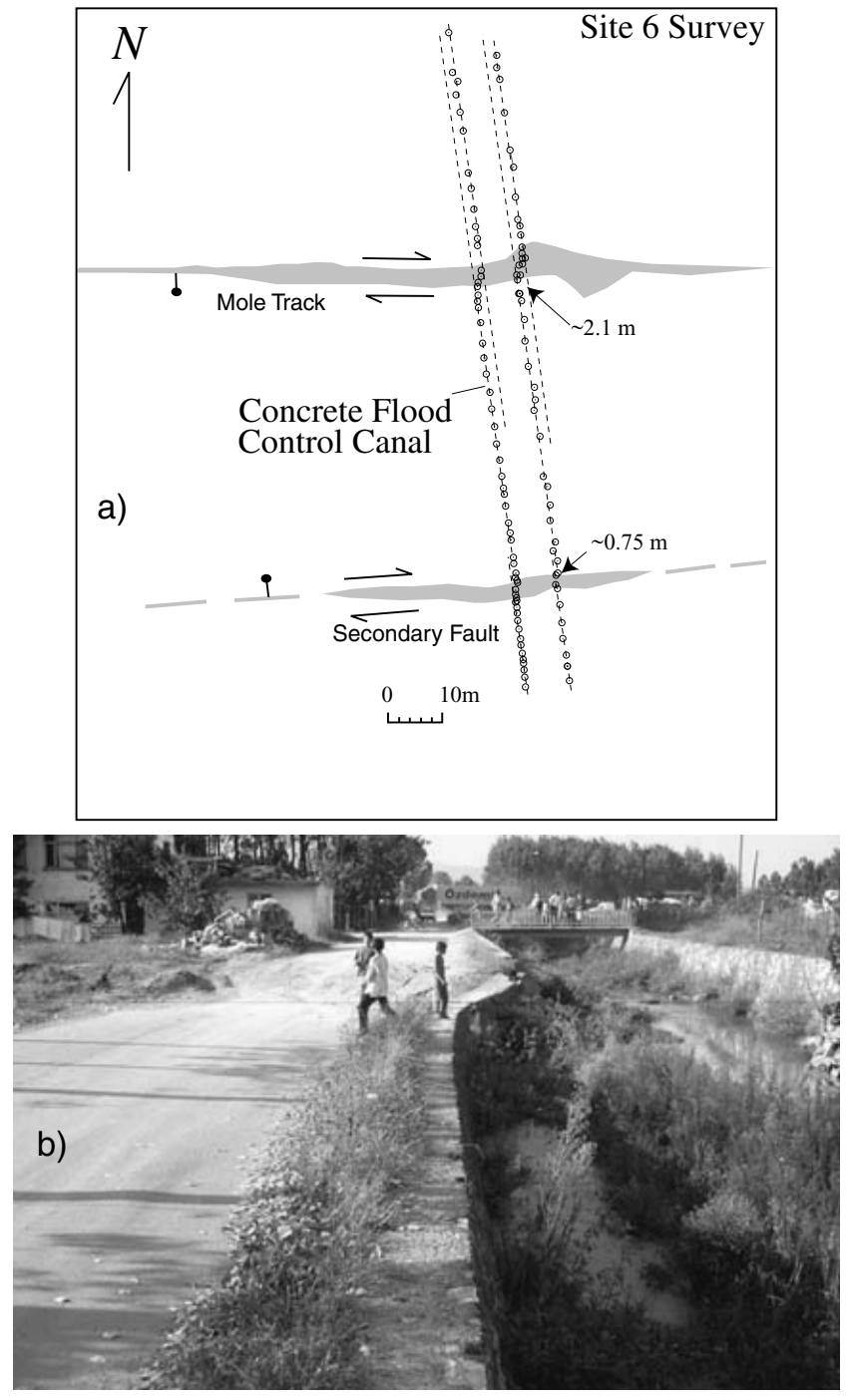

Figure 4. (a) Survey of a flood control canal constructed with concrete and stone at site 6. (b) Photograph of west wall of canal. Note the linear nature of the inside edge of the wall that we surveyed and the warping and displacement at the main fault.

post was surveyed to establish the location of this strain marker (Fig. 5). We estimate the total lateral slip at site 8 to be $3.7 \mathrm{~m}$, of which about $0.65 \mathrm{~m}$ is warping.

Site 7 consists of an offset concrete wall along the west perimeter of a newly constructed complex of apartment buildings that were razed following the August earthquake due to extensive collapse and structural damage (figure 15 of U.S. Geological Survey, 2000). Because the fault trace was buried beneath the building rubble east of the wall, we could only survey the location of the fault zone west of the fault (Fig. 6). Based on reconstruction of the wall at site 7 , we estimate $2.75 \mathrm{~m}$ of lateral slip, of which $0.75 \mathrm{~m}$ is offfault deformation.

Sites 8 and 7 are both single linear offset features near İzmit Bay (Fig. 1). In both cases, these linear features are

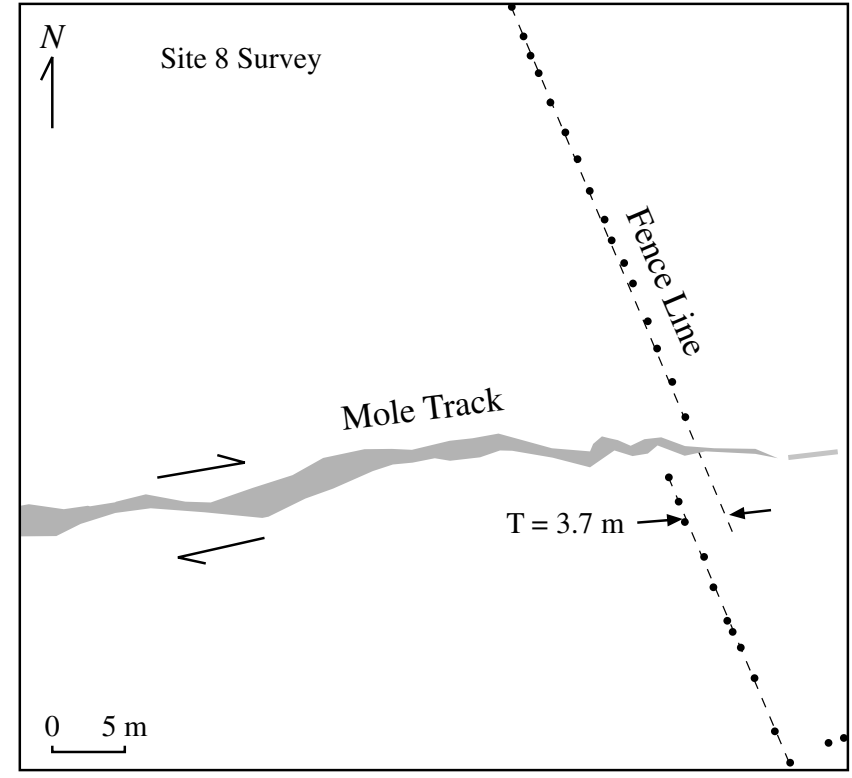

Figure 5. Survey of a fence line (barbed wire on wooden posts) at site 8 . The fence alignment is parallel on each side of the fault, and the zone of deformation appears quite narrow, less than $3 \mathrm{~m}$.

parallel on each side of the fault, and the zone of deformation is narrow, less than $5 \mathrm{~m}$. Error in both cases is low; we estimate that a deflection or overreconstruction of more than about $20 \mathrm{~cm}$ would be observable because of the linearity of these features, so we use this as an estimate of the error. These observations, combined with those from site 6 , show that where the fault approaches İzmit Bay, slip appears to vary by nearly $1 \mathrm{~m}$ at the surface over a lateral distance of 2-3 km.

Site 11 is a small grove of three tree lines near Kosekoy (Figs. 1 and 7). We surveyed the three lines of trees and resolved slips of 1.9, 1.8, and $2.25 \mathrm{~m}$ for the three tree alignments, all of which agree within the $20-30 \mathrm{~cm}$ of error. They are also very similar to measurements recorded in the area immediately after the earthquake (Barka et al., 2000).

Site 10, also along the Sapanca segment, consists of two parallel lines of tree stumps near Tepatarla (Figs. 1 and 8). Stumps have the advantage over living trees because the center of the stump can be sighted with the pole directly, there are no visibility problems as in a grove of trees, and there is less variability in growth direction at ground level. We surveyed all the stumps present, but the rows of stumps only extend $10 \mathrm{~m}$ north of the fault and $20 \mathrm{~m}$ south of it. As we have observed other zones of deformation that were at least this wide, slip estimates for this site may represent minimum values. This suggestion is supported by the observation that the stump lines are not exactly parallel on each side of the fault and that at least one additional minor fault may be represented by a step in the stump line about 15-20 m south of the main fault. We fixed the trend of the tree line north of the fault to establish slip and assume that most or 


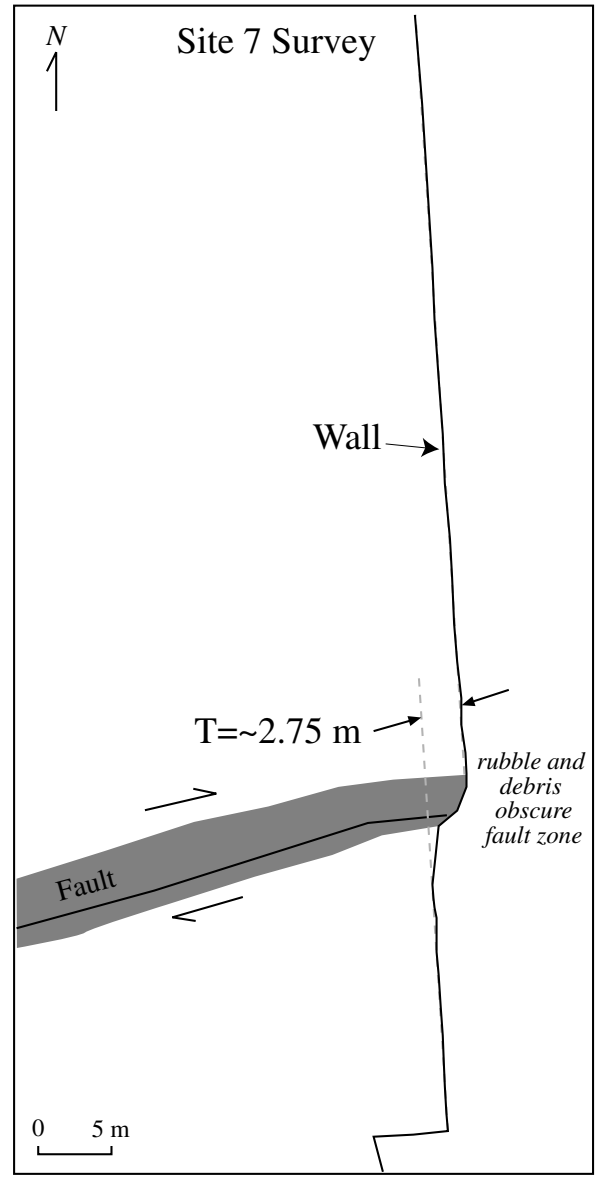

Figure 6. Survey of a wall at site 7 . The wall is all that remains of a destroyed and torn-down apartment building complex offset by the earthquake. The eastern portion of the fault was obscured by debris from the building rubble at the time of the survey.

all of the warping occurs to the south of the fault. The other possibility, that of fixing the trend south of the fault, requires that the trees to the north are reverse-dragged into the fault. We consider this less likely. Thus, we consider the similar estimates of 3.65-3.85 m (from both rows of stumps) across the entire zone to best represent slip at this site. This value is similar to the maximum surveyed value near Izmit Bay and suggests that slip at depth may be 3.5-4 m for the Sapanca segment of the August rupture.

\section{Sakarya Segment: 17 August Rupture}

Sites 9, 4, and 5 are located along the Arifiye segment that sustained the highest measured slip during the August earthquake (Figs. 1 and 2) (U.S. Geological Survey, 2000; Langridge et al., 2002). We confirmed those results with our surveys but generally determined slip values that were larger than those measured during the weeks that followed this event. At each of these three sites, we surveyed multiple lines of trees across the fault zone.

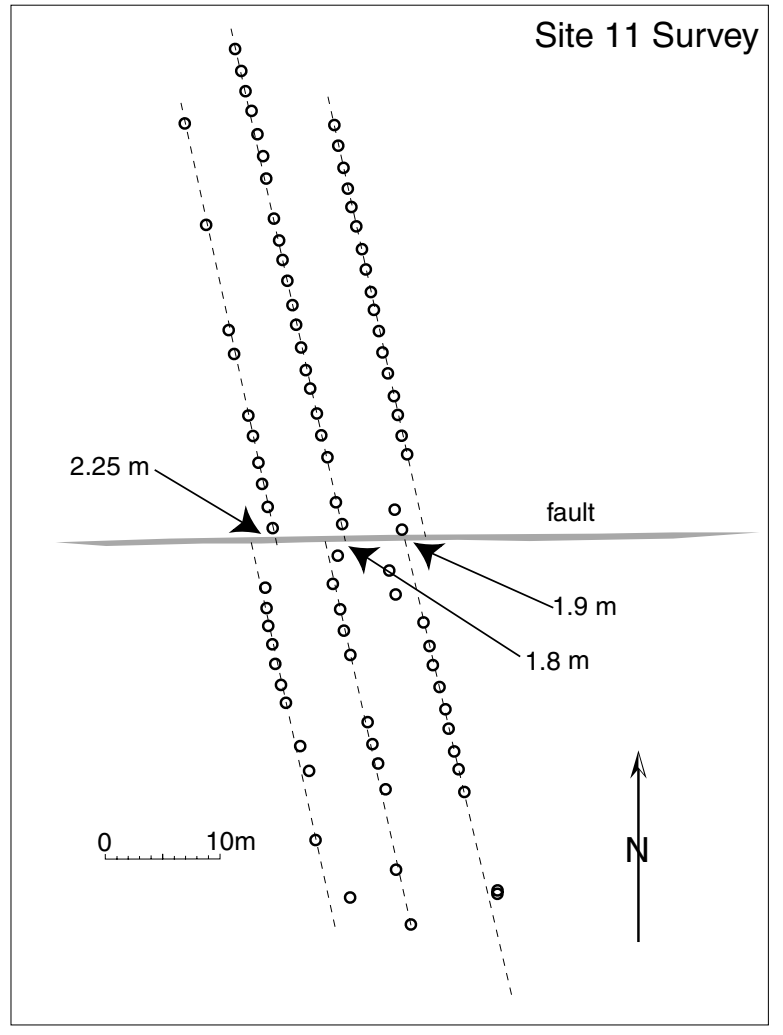

Figure 7. Survey of three tree lines near Kosekoy, with slip ranging between 1.8 and $2.25 \mathrm{~m}$, similar to tape measurements taken soon after the earthquake. Slip also occurred on nearby secondary faults that were not crossed by the tree lines.

At site 9, we surveyed 12 lines of trees at the orchard near Arifiye, where the maximum slip value of $5.1 \mathrm{~m}$ (Akyuz et al., 2000; Barka et al., 2000) was measured after the earthquake (Figs. 1 and 9). For the western portion of the orchard, the entire zone of deformation appears to be within a width of 2-4 m, and the trees are parallel on each side of the fault (Fig. 9). Toward the east, the fault zone broadens to about $10 \mathrm{~m}$, with nearly all the deformation within this zone. Although the lengths of our surveys extend up to $100 \mathrm{~m}$ on each side of the fault, the actual distance perpendicular to fault is only as much as $60 \mathrm{~m}$ because the tree lines are oriented at about $40^{\circ}$ to the fault. Furthermore, a field boundary obliquely intersects the fault and disrupts the tree alignments, resulting in significantly shortened tree rows for some alignments (Fig. 9).

We reconstructed the surveys to resolve slip measurements that ranged between 3.4 and $5.2 \mathrm{~m}$. The errors are relatively larger in some cases because some tree lines were not planted perfectly straight, and all the rows are at a moderate angle to the fault.

The slip appears to increase across the grove from west to east, with the maximum slip measurements along the easternmost trees at about $5.2 \mathrm{~m}$. By assuming originally straight tree rows, we resolved $5.15 \mathrm{~m}$ of slip for row 11 and $5.2 \mathrm{~m}$ 


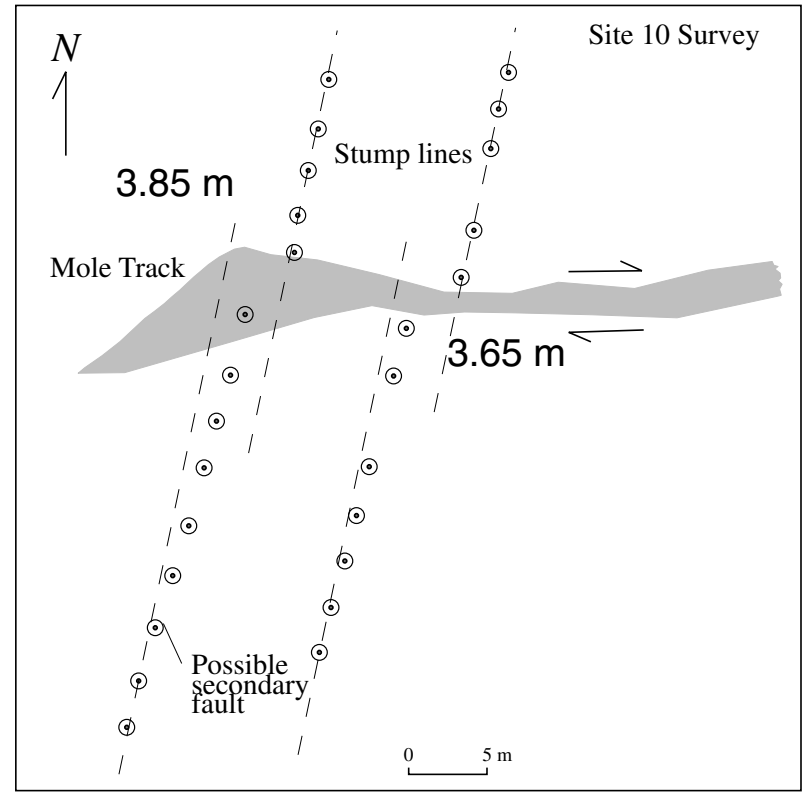

Figure 8. Survey of two parallel stump lines at site 10. Slip is estimated at about 3.65 and $3.85 \mathrm{~m}$ for the west and east lines, respectively. However, the stumps south of the fault are not exactly parallel to those north of it, suggesting that the zone of warping equals or exceeds the length of the stump line. Thus, these slip estimates are probably minimum values.

of slip for row 12, confirming the field measurements taken by tape measure after the earthquake on these same trees. In both cases, error is estimated at about $25 \mathrm{~cm}$ based on minor irregularities in tree planting and in our inability to resolve primary configuration versus deformation.

In any case, slip clearly varies across this grove by up to $1.8 \mathrm{~m}$ over a lateral distance of about $100 \mathrm{~m}$ between rows 5 and 12 (Figs. 9 and 10). Moreover, the 3.4-m measurement of row 5 is about $1 \mathrm{~m}$ less than for adjacent rows 4 and 6 that are only $10-15 \mathrm{~m}$ apart. In the field, we could not find other fault strands that may have accommodated this deformation nor were any reported from the surface rupture mapping immediately after the earthquake (Barka et al., 2000). However, because our survey measurements were made months after the earthquake and after several significant rainfalls, we cannot preclude minor secondary strands. This could partially explain the variability of measured slip in the grove.

Site 4, located west of the Sakarya River (Fig. 1), consists of a group of four stump lines and three tree lines (Fig. 11). In the weeks following the earthquake, $3.47 \pm 0.3 \mathrm{~m}$ of slip was measured on one of the tree lines, and about 3.3 $\mathrm{m}$ of slip was measured on a wall east of the grove (Langridge et al., 2002). This wall, as shown in Figure 11, had been rebuilt prior to our November survey, and there was no indication of rebreakage after its reconstruction, indicating that there was no afterslip since reconstruction of the wall. The fault crosses obliquely through the grove of trees and stumps, so the zone of deformation is only completely crossed by the eastern five tree lines. In fact, the western two stump rows only have one stump north of the fault, resulting in minimum slip estimates only. Also, the individual lines of trees and stumps only measure $40 \mathrm{~m}$ in length, but they are generally parallel away from the fault zone. To maximize the usefulness of the stump lines that do not extend very far north of the fault, we analyzed the stump and tree spacing across the deformation zone to estimate slip for each alignment. Assuming relatively straight tree lines prior to the earthquake, we estimate slip increases from about 3.3 (minimum) to $4.55 \mathrm{~m}$ across a lateral distance of $40 \mathrm{~m}$ (Figs. 11 and 12). Of note is the observation that slip appears to increase gradually and systematically across the grove to the east, as shown in Figure 12.

Site 5 is located along the Sakarya River, east of site 4, where we surveyed four tree lines on the terrace adjacent to the stream bank (Fig. 13). We also surveyed the stream bank, but collapse (lateral spreading) of the channel bank led to very large uncertainties in the actual slip, so we did not use the stream bank offset for a slip estimate. Liquefaction was extensive at this site, and its effects on the tree alignments are unknown. Again, the fault crosses obliquely through the grove of trees, so we may miss some slip if we did not capture the entire width of deformation. In all cases, the trees are parallel on each side of the fault zone, which supports the contention that we did capture most or all of the slip. Also, in this case, slip increases toward the east, away from the river, and where the survey line extends the shortest distance beyond the fault. Projecting the tree lines across the fault and reconstructing them yields values of about 4.2-4.3 $\mathrm{m}$ for the western three lines and $5.1 \mathrm{~m}$ for the eastern tree line. The western tree lines appear to completely cross the fault zone. The eastern tree line has a broad zone of warping, and only the northern two trees have the same trend as the trees toward the south end of the line. The $5.1 \mathrm{~m}$ is over 0.5 m greater than the other three tree lines (Fig. 14) and either represents a significant increase in slip over a very short lateral distance or an irregular and unparallel planting of the trees in row D on the south side of the fault. This apparent lateral variation may also reflect the possible effects of liquefaction and lateral spreading, although we did not observe a deflection in the tree alignments over the distances surveyed.

\section{Düzce Segment: 12 November Rupture}

Sites 1-3 are along the 12 November Düzce surface rupture, with two surveys located near Eften Golu and one at Kaynasli (Fig. 1). The Eften Golu sites involved measurement of offset concrete walls and a chain-link fence at site 1 and an offset elevated concrete flume at site 3 . Within an orchard in the town of Kaynasli, we surveyed an offset barbed-wire fence mounted on concrete posts at site 2 .

Because no single cultural feature spanned the entire width of the fault zone at site 1, we surveyed two walls and 


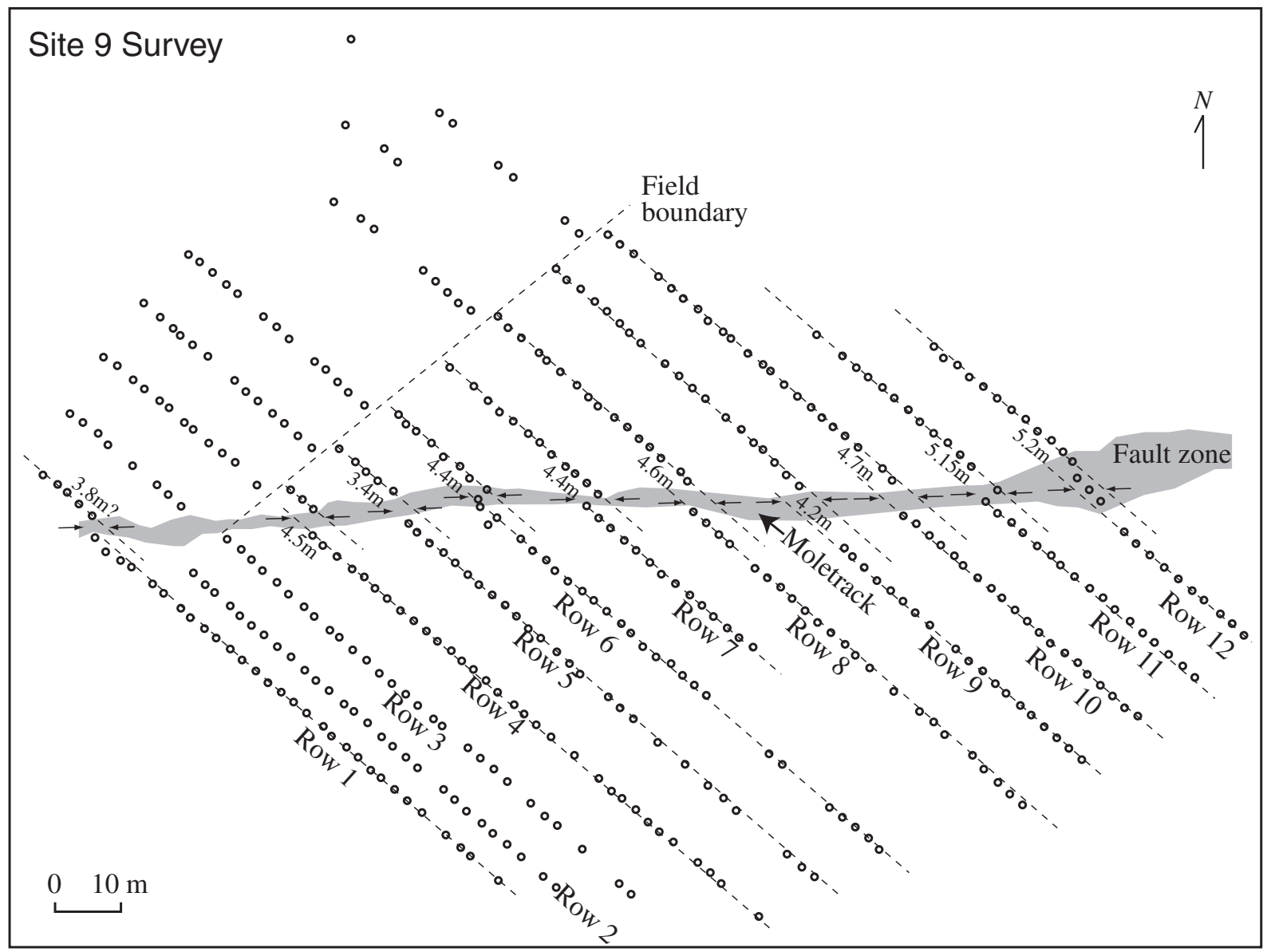

Figure 9. Survey of site 9, where maximum slip was reported in tree rows 11 and 12, after the August earthquake. Note that slip is generally in the range of $4.5-5 \mathrm{~m}$, increasing eastward, but that tree row 5 has a substantially lower value of slip $(3.4 \mathrm{~m})$. Tree row 1 also appears to have a lower slip value but has large associated uncertainties.

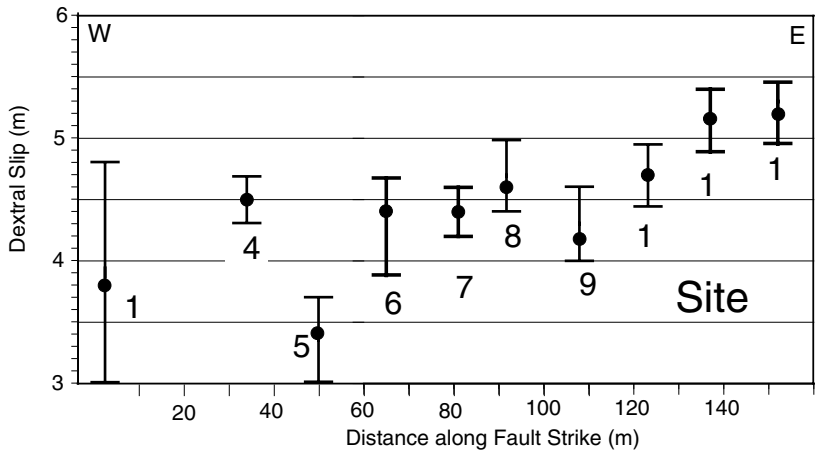

Figure 10. Variability of slip through grove at site 9, showing mean values and uncertainties.

a chain-link fence in an attempt to measure the total deformation at this site (Fig. 15). A low ( $<1 \mathrm{~m}$ high) concrete wall (with an upper chain-link portion) extends north and south beyond the main fault zone by about $18 \mathrm{~m}$ and $13 \mathrm{~m}$, respectively, but does not cross the secondary fault located about $32 \mathrm{~m}$ south of the main zone. This wall was con- structed across a large pre-existing scarp ( $~ 5 \mathrm{~m}$ high) that may have had significant fluvial modification. A taller rock wall ( $\sim 2 \mathrm{~m}$ high) with a concrete cap and a separate chainlink fence were surveyed to capture slip on the secondary strand and to measure any nonbrittle warping that may have occurred south of the main strand (Fig. 15).

On the south, or mountain, side of the main fault, the short wall is outside of the zone of faulting, and we assume this to represent the original orientation for this feature. For several meters adjacent to the fault on the south side, the wall appears to bow out to the west (downslope), which may represent several tens of centimeters of downslope movement related to tensional cracking in the slope or fling of the concrete during the earthquake. We use the linear wall segment south of this disturbed zone for our reconstruction. On the north, or valley, side of the main fault, the wall bends and expresses a zone of warping for about $10 \mathrm{~m}$ north of the main trace. Only the northernmost section appears to be undeformed and have the same trend as the wall south of the fault (Fig. 15). If correct, then by projecting the same trend of the wall across the fault and zone of warping, we estimate 


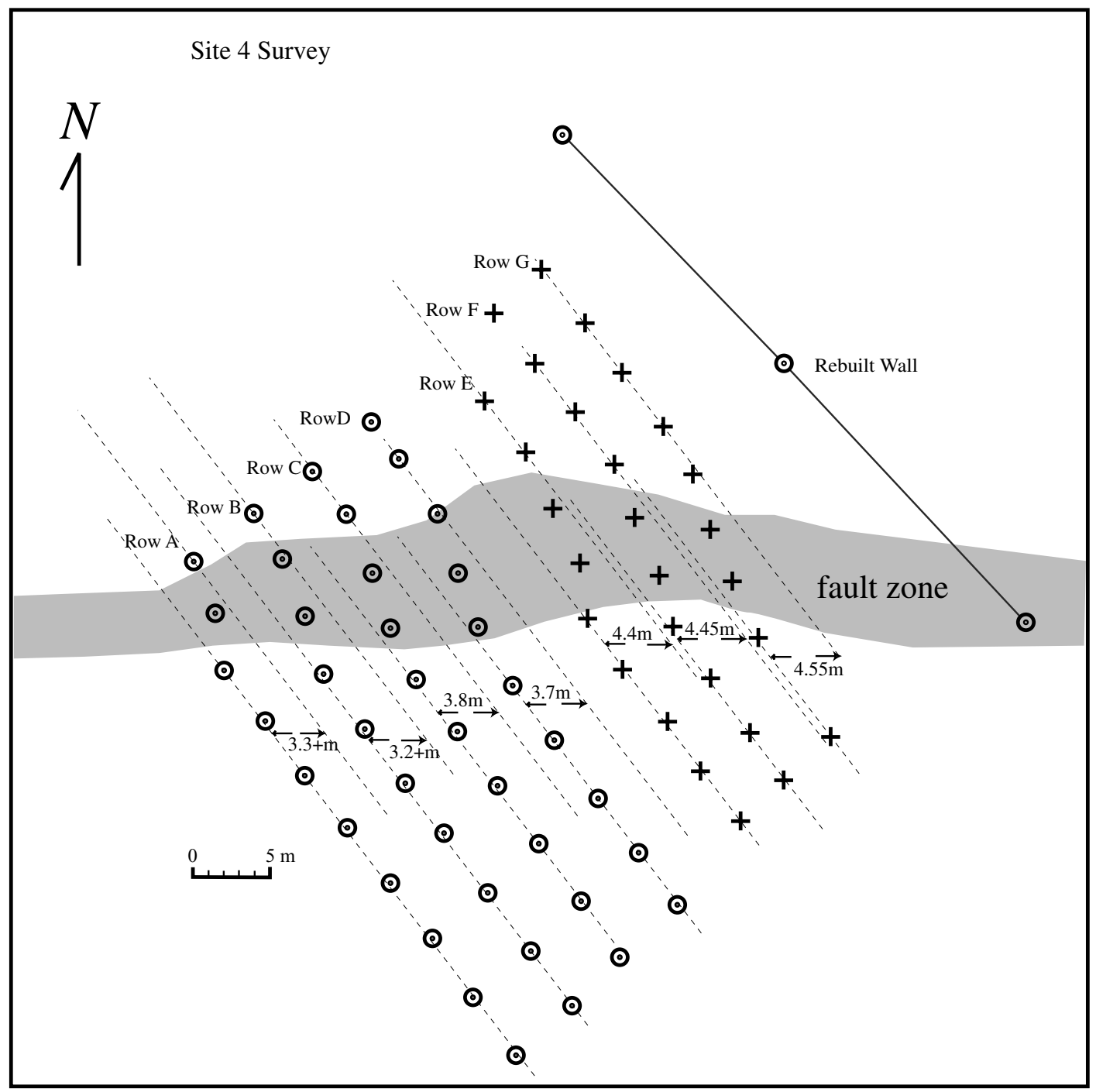

Figure 11. Survey plot from site 4 showing four stump lines (rows A-D) and three tree lines (rows E-G) that are offset across the fault. Slip after the earthquake was reported from the fence line along the east side, which has now been rebuilt. Note that the western stump lines only have one stump north of the fault, so these are interpreted as minimum values because these rows may not capture the entire zone of deformation.

about $3.2 \pm 0.4 \mathrm{~m}$ of right-lateral slip, of which about 40 $\mathrm{cm}$ is by warping.

A secondary fault strand is evident about $30 \mathrm{~m}$ south of the main zone. The tall wall is linear and parallel, both to north and to south of this secondary fault, and there is no apparent warping beyond the very narrow secondary fault zone. We estimate an additional $0.6 \pm 0.05 \mathrm{~m}$ of dextral slip across this southern strand, yielding a total slip of about $3.8 \pm 0.4 \mathrm{~m}$.

At site 3, a concrete flume crosses a 5-m-wide zone of faulting and extends $10 \mathrm{~m}$ to the south of the fault and about $50 \mathrm{~m}$ to the north of it (Fig. 16). It appears that this site experienced significant off-fault deformation, so we aligned the straight section of the flume south of the fault with the parallel section of five survey points north of the fault to measure slip. Immediately adjacent to the fault, the flume is apparently reverse-dragged into the fault, due to rigid rotation of the concrete flume in the zone of deformation. Ignoring the rotations within the fault and using the projected alignments shown in Figure 16, we determined $3.8 \pm 0.5$ $\mathrm{m}$ of total right-lateral slip for this site.

Site 2 at Kaynasli is a line of concrete fence posts that cross a 5-m-wide zone of faulting that includes a 2-m-wide mole track and a secondary splay (Fig. 17). The trend of the fence posts to the north and south of the fault is discordant, although there was no clear reason why this should be the case other than broad, distributed shear. To the north of the fault, the posts are found in alluvium and have a more northeasterly trend than to the south of the fault (presumably shallower bedrock), suggesting that the end of the survey $10 \mathrm{~m}$ 


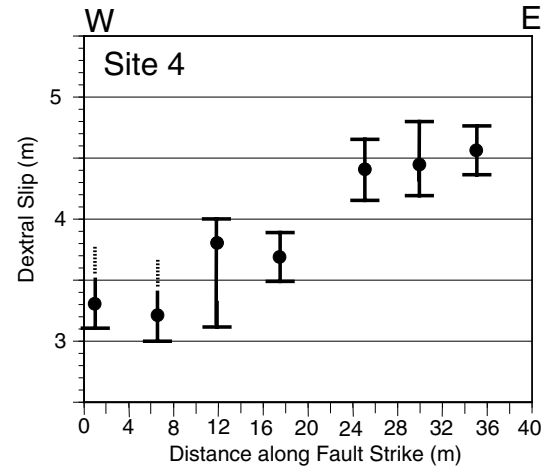

Figure 12. Variability of slip through the Kavak grove at site 4 , showing mean values and uncertainties. Note the apparent systematic increase in slip from west to east.

north of the northernmost fracture is not completely outside the zone of warping. This is supported by observations of additional fractures, $25-30 \mathrm{~m}$, to the northwest (Fig. 17). If correct, then the total dextral shear is substantially more than that indicated by the brittle displacement at the fault. To estimate slip, we use the near-field slip on the principal strand of $2.0 \mathrm{~m}$ as a minimum value. For a maximum value, and one that we suspect reflects the actual slip, we project the fence line into and across the fault, using the strike of the fence south of the fault and the northernmost fence post as a tie, assuming the fence was straight prior to the earthquake (Fig. 17). This yields a higher total estimate of slip of $3.45 \mathrm{~m}$ for site 3 , which is consistent with the maximum postearthquakes measurements in the Kaynasli region (Akyuz et al., 2000).

Comparison with Field Measurements Taken after the Earthquakes

We compared our estimates of slip based on surveyed alignments with the field estimates taken after each of the two surface ruptures. For the Sakarya segment, we made the field slip estimates reported by Barka et al. (2000) for some of the same sites we surveyed, so we attempted to relocate the same features that we described during August. However, from our surveying of parallel lines of trees and the significant variability of slip that we observe over short lateral distances, we cannot be certain that in some cases we actually observed the same tree line, even though we made many of the initial measurements. For the Düzce rupture, we compare our results with those of Akyuz et al. (2000) and Hartleb et al. (2002) and are certain that the features are the same for at least sites 1 and 3 (Hartleb, 2000, personal comm.).

For the Sapanca segment, slip was reported as being lower than slip either to the east (Arifiye) or to the west (Golcuk area) (Barka et al., 2000). We reconfirm these observations; however, we report higher slip values based on the surveys at sites 8,11 , and 10 than were recorded after the earthquake. Slip along this segment appears to range from about 1 to $3 \mathrm{~m}$ from the field mapping, whereas the survey measurements ranged between 1.8 and $3.85 \mathrm{~m}$ (Fig. 2). We take the mean slip value at each of the five survey sites to calculate an average slip of about $3 \mathrm{~m}$ for the Sapanca segment we surveyed during November. The fence line at site 8 and the stumps at site 10 offset yield significantly greater amounts of offset than reported in postearthquake investigations (Barka et al., 2000; Langridge et al., 2002). We attribute these differences primarily to either misrecognition of slip after the earthquake or lateral differences in slip along the rupture rather than to afterslip, as we saw no evidence of recracking of repaired roads or other linear features that would suggest continued slip.

For the Sakarya segment east of Lake Sapanca, we also reconfirm the observations of high slip. At site 9 , which we measured after the earthquake as $5.1 \mathrm{~m}$ on the same line of trees (Barka et al., 2000; U.S. Geological Survey, 2000; Langridge et al., 2002), our survey results indicate a slightly higher slip of 5.15-5.2 m. Considering the errors in both cases, these estimates are indistinguishable. Along the Sakarya River at site 5, however, we had measured the trees close to the river as being offset a little over $3 \mathrm{~m}$, whereas our survey results indicate higher values of 4-5 $\mathrm{m}$. The three western tree lines all show slip in the range of 4.2-4.4 m, whereas the easternmost tree line reconstructs to $5.1 \mathrm{~m}$ of dextral offset. Slip at this site is substantially more than that reported after the earthquake, with an average value of 4.5 $\mathrm{m}$. This is $1.2 \mathrm{~m}$ higher than the value of 3-3.3 m reported in August and better matches the deep slip observed by geophysical methods. This illuminates the need to collect abundant, closely spaced observations rather than few, widely spaced slip measurements. It also illustrates the errors that are inherent from making near-field measurements without a sufficient reference frame.

For the Düzce rupture, our three surveyed offsets are also generally higher than those reported from the field observations. For instance at site 3 , we estimate a value that is over $2 \mathrm{~m}$ higher on what we are certain is the same feature that was measured by the Düzce mapping team (Akyuz et al., 2000). At site 2 , we determined about $0.5 \mathrm{~m}$ more slip than was measured by the mapping teams. Our measurement at site 1 , in contrast, falls within the range estimated by Hartleb et al. (2002). Along the İzmit-Sapanca and Sakarya segments, one can invoke afterslip as a partial explanation for the differences. However, as we made our measurements during the same time period as Akyuz et al. (2000) and Hartleb et al. (2002) for the November rupture, these differences appear to reflect primarily the difference between near-field estimates of slip and those based on survey of long, linear features. Some of the differences can be attributed to our observation on significant lateral variability of slip and the likelihood that the highest slip along any section of fault was actually measured. In many cases, it is possible that the largest displacement feature is not measured after an earthquake if measurements are spaced fairly broadly. Nevertheless, in 


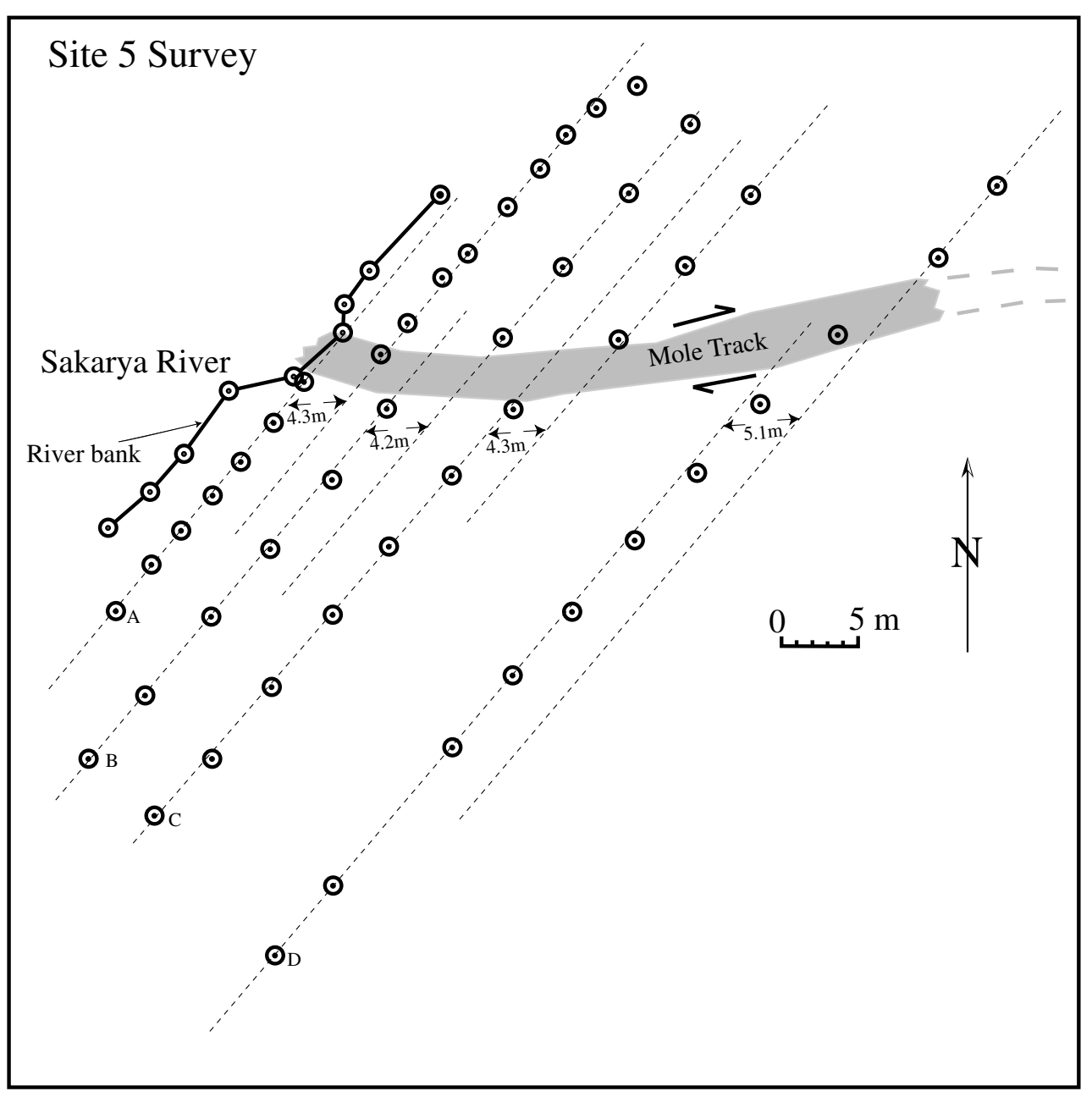

Figure 13. Survey plot of site 5 showing the alignments of four tree rows across the fault. Note that the eastern line of trees, which has the greatest amount of apparent slip, has the least coverage north of the fault.

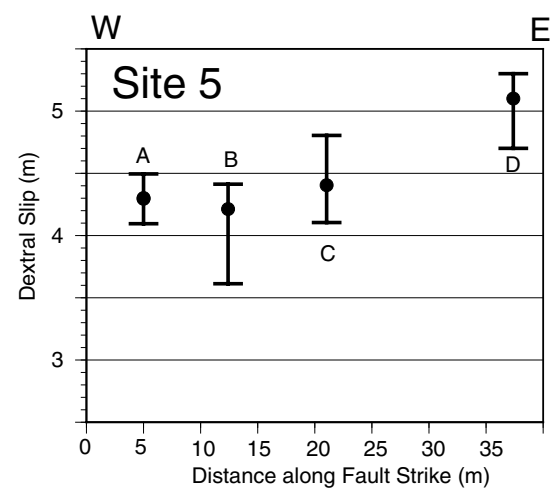

Figure 14. Variability of slip through the Kavak grove at site 5, showing mean values and uncertainties. that most of the measurements are known to have been taken on the same feature, we attribute much of the difference to the contribution of off-fault deformation. We include nearfault warping along with our estimates of brittle slip when the surveyed markers have significant spacing between them, which may partially explain why even our estimates of near-field slip are generally larger than those reported from field estimates alone. The possibility of afterslip remains a partial possibility for explaining our differences in slip, especially near İzmit.

These observations are important for interpreting geomorphically derived displacements along active faults (Lindvall et al., 1989; McGill and Rubin, 1999). We observed an average of about $15 \%$ of the strain accommodated by nonbrittle shear, with individual observations ranging from $0 \%$ to $40 \%$. The actual average may even be higher in that we may have included some near-fault bending in our estimates of brittle slip (Table 2). Part of this lateral deformation is accommodated by bending or drag in a zone as much as 30 


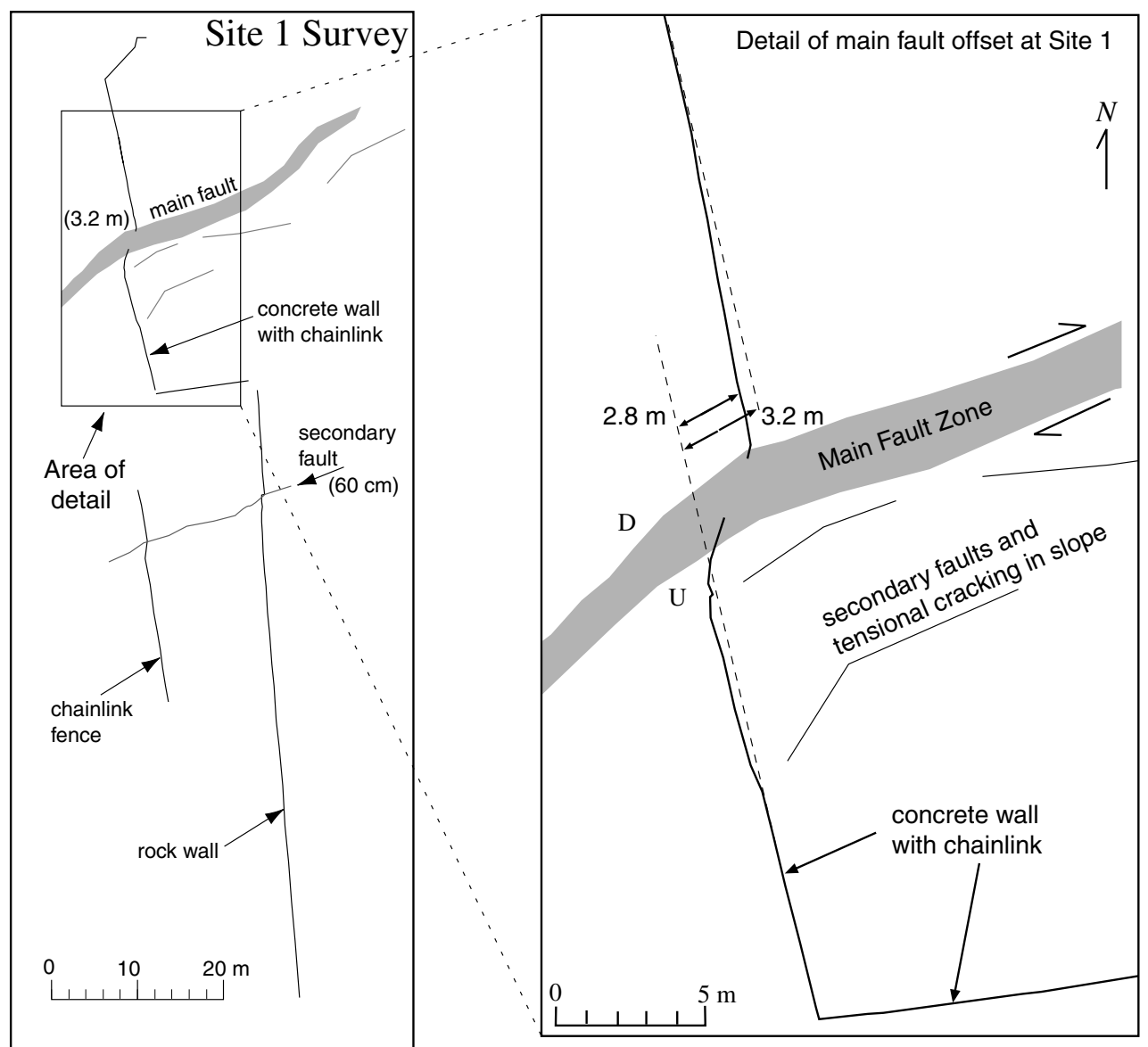

Figure 15. Survey plot from site 1 showing a wall offset by the main faults and another wall and chain-link fence offset by a secondary fault. Note that no single cultural feature spanned the entire width of deformation at this site.

$m$ in width, although usually the zone varies between 5 and $20 \mathrm{~m}$ in width. This supports the idea that substantial nonbrittle, off-fault deformation is associated with ruptures in areas of alluvial fill and argues strongly for the concept of construction set backs from active faults. In areas of substantial off-fault deformation, our observations suggest that postearthquake field measurements of slip based on offset geomorphic features alone may underestimate the actual amount of slip in that event. Furthermore, measurements based on brittle offset of deposits exposed in trenches may also represent a minimum of the total slip, thereby leading to underestimates of slip rate, displacement per event, or inferred earthquake magnitude.

\section{Lateral Variability and Its Implications}

Multiple alignments were surveyed at six of our sites, and in most cases, the estimates of slip vary significantly, even for tree lines and walls that are only a few meters apart (Figs. 2, 10, 12, and 14). We are surprised by this result because in many of these alignments the strain does not appear to be simply accommodated by bending or other non- brittle deformational styles. It does not appear to extend to nearby alignments of trees or walls, and there seems to be a systematic increase in one direction rather than random variations.

The maximum slip of about $5.1 \mathrm{~m}$ was measured in September, east of Sapanca at our site 9 by the mapping team (Barka et al., 2000; U.S. Geological Survey, 2000; Langridge et al., 2002). We reconfirm this result and measured about 5.15 and $5.2 \mathrm{~m}$ of slip on the same alignments of trees. However, within this grove of trees, surveyed slip measurements vary by up to $1.8 \mathrm{~m}$ over a $100 \mathrm{~m}$ horizontal distance and up to nearly $1 \mathrm{~m}$ over distances of only 10-15 $\mathrm{m}$. As we have long survey transects that appear to encompass the entire width of the deformation zone, there appears to be real lateral variability over a relatively short section of the fault. This is consistent with observations made soon after the earthquake, as well as from two other of our surveys at sites 4 and 5 . The alternative explanation is that slip is stepping from the main strand to another unmapped and unrecognized secondary strand. The problem with this interpretation is that the primary 1999 rupture strand continues for a much greater length than the distance over which the 


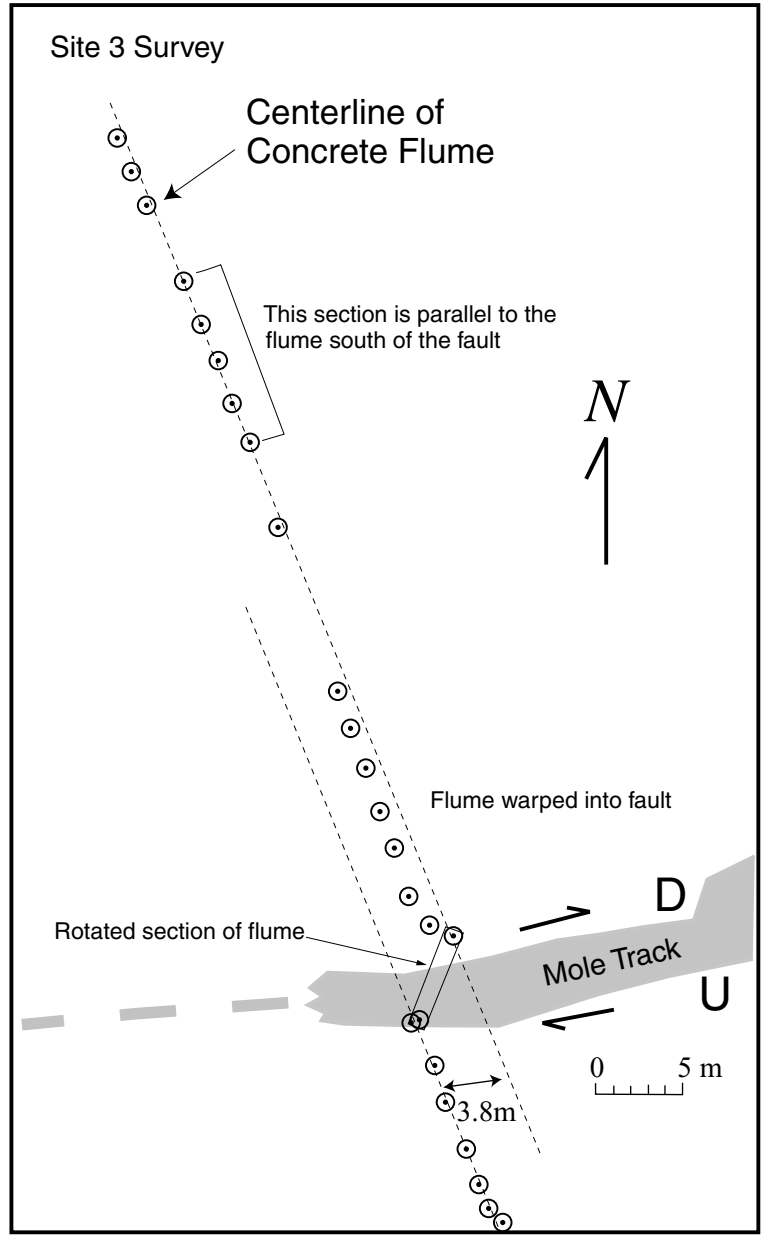

Figure 16. Survey plot from site 3 showing a displaced concrete flume. Note the apparent fling of the flume section within the main fault zone and the apparent warping of the flume farther north of the fault.

change in slip occurs, and another postulated strand with a slip of $1 \mathrm{~m}$ should have been easily recognized.

In each of the cases of observed variability in slip, there is as much as $20 \%-25 \%$ difference between the lowest and highest values. This is far outside of our estimates of error and are difficult to explain by other mechanisms. These observations of variability have significant implications for models of real earth deformation, in that these strains are occurring over short lateral distances. Further, they mean that offsets derived from trenches may not accurately reflect slip for a section of fault, even if far-field deformation is not an issue. These values are similar to those described for variability in offset geomorphic features mapped after the Landers and Hector Mine earthquakes (Hector Mine Working Group, 2000).

The aforementioned observations suggest that the 1999 Turkey ruptures may be the best case yet for defendable lateral variability of slip over short distances. In most of the previous studies, offsets were measured on either geomor-

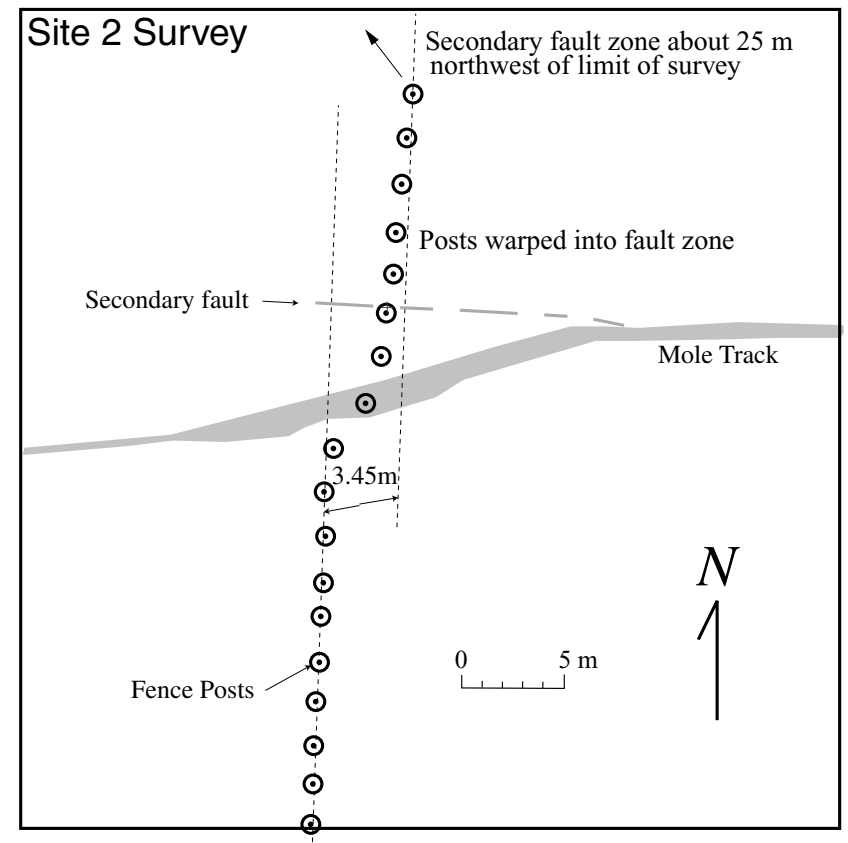

Figure 17. Survey plot from site 2 showing a displaced fence line. Note that the northern alignment of the fence, which is in alluvium, is not parallel to the fence south of the fault where bedrock is presumed to be shallower.

phic features, for which the pre-earthquake configuration cannot be determined without substantial error, or cultural features that are too short to record distributed, off-fault strain. In Turkey, long rows of poplar trees planted in fairly straight $( \pm 15-20 \mathrm{~cm})$ lines may make for a remarkable analysis of strain variability.

\section{Discussion and Conclusions}

Our long baseline surveys of cultural features, offset in the İzmit and Düzce earthquakes of August and November 1999, show that many, closely spaced measurements are required in order to adequately resolve slip for a section of fault. Widely spaced measurements may miss areas of higher slip that may be more representative of slip at depth. Furthermore, we observed evidence of significant off-fault deformation of an average of about $15 \%$ of the total, with as much as $40 \%$ for some features. In most cases, the higher values of warping are due to rotation of rigid structures, such as concrete canals and walls, but even some tree lines experienced broad zones of deformation with large components of nonbrittle shear. Much of this off-fault deformation was apparently not recognized by the field mapping teams, as a long baseline reference frame is required. Thus, measurement of only the near-field slip using tape measures potentially underestimates the actual slip for the earthquake and slip distribution for the overall surface rupture. Field measurements of even long features may underestimate slip 
because it is very difficult to resolve far-field bending in the field. This is evident from the Düzce rupture, where long, linear features were measured by both the methods, and the surveyed results yielded consistently higher values. Measurement of very near-field geomorphic features is expected to be even more problematic, especially in alluvium, and should be considered minimum values.

We found that errors in slip estimation for surveyed features may be significant, even for long, linear structures that look very good in the field. In our best-case examples, we estimate uncertainties on the order of $15-20 \mathrm{~cm}$. For a couple measurements, uncertainties are about $1 \mathrm{~m}$. In some cases, our slip estimates and associated errors did not overlap with those made in the field after the earthquakes, which were based on near-field measurement techniques (tape measure). We suggest from these observations that field estimates of slip may commonly underestimate errors associated with slip measurements and that actual errors for relatively long baseline features may be very large because it is very difficult to see broad warping in the field. We experienced this phenomenon in several cases in that many of the features we surveyed appeared dead parallel in the field yet were found to record some rotational strain. We recommend that surveying of long baseline cultural features be considered a routine task performed along with field mapping after every surface-rupturing earthquake. We also suggest that alignment arrays and other surveying monuments be established immediately after a surface rupture to assess the presence of afterslip, as we cannot preclude this as a partial explanation for the observed differences in this study.

\section{Acknowledgments}

We first and foremost thank the wonderful people of Turkey for welcoming us with open arms after such a terrible disaster. Many landowners granted access for the surveying work, and many local Turks provided useful discussions on individual features and their original configurations. We thank Pacific Gas \& Electric Company for funding most of this project, and especially Bill Page for his direction during the early phases of the field investigation, but we accept full responsibility for any misinterpretations that may evolve out of this work. The Southern California Earthquake Center provided support for R. L. to fly over and join the surveying team. Finally, we thank Aykut Barka for his unwavering support and assistance in Turkey in all phases of our work, including providing students to help with translations. Without Aykut and his Turkish colleagues, work in Turkey would have been much more difficult and not nearly as much fun. This research was supported by the Southern California Earthquake Center. SCEC is funded by NSF Cooperative agreement EAR-8920136 and USGS Cooperative agreements 14-08-0001-A0899 and 1434-HQ-97AG01718. The SCEC Contribution Number for this article is 615 .

\section{References}

Akyuz, H. S., A. Barka, E. Altunel, R. Hartleb, and G. Sunal (2000). Field observations and slip distribution of the November 12, 1999 Düzce earthquake (M 7.1), in Istanbul Technical University Special Publication on the August 17 and November 12 Earthquakes, A. Barka (Editor), (in press).

Barka, A., S. Akyuz, E. Altunel, G. Sunal, Z. Cakir, A. Dikbas, B. Yerli,
T. Rockwell, J. Dolan, R. Hartleb, T. Dawson, T. Fumal, R. Langridge, H. Stenner, S. Christofferson, A. Tucker, R. Armijo, B. Meyer, J. B. Chabalier, W. Lettis, W. Page, and J. Bachhurber (2000). The August 17, 1999 İzmit earthquake, $M=7.4$, eastern Marmara region, Turkey: study of surface rupture and slip distribution, in The 1999 İzmit and Düzce Earthquakes: Preliminary Results, A. Barka, O. Kozaci, and S. Akyuz (Editors), Istanbul Technical University, Istanbul, $15-30$.

Clark, M. M. (1972). Surface rupture along the Coyote Creek fault in The Borrego Mountain Earthquake of April 9, 1968, U.S. Geol. Surv. Profess. Pap. 787, 55-86.

Hartleb, R. D., J. F. Dolan, S. Akyuz, T. E. Dawson, A. Z. Tucker, B. Yerli, T. K. Rockwell, E. Toraman, Z. Cakir, A. Dikbas, and E. Altunel (2002). Surface rupture and slip distribution along the Karadere segment of the 17 August 1999 İzmit, Turkey, earthquake, Bull. Seism. Soc. Am. (Special Issue on the 1999 İzmit and Düzce, Turkey, Earthquakes, N. Toksoz [Editor]).

Hudnut, K., L. Seeber, T. K. Rockwell, J. Goodmacher, R. Klinger, S. Lindvall, and R. McElwain (1989). Surface ruptures on cross-faults in the 24 November, 1987 Superstition Hills, California, earthquake sequence, Bull. Seism. Soc. Am. 79, no. 2, 282-296.

Langridge, R. M., H. D. Stenner, T. E. Fumal, S. A. Christofferson, T. K. Rockwell, R. D. Hartleb, and A. A. Barka (2002). Geometry and slip distribution of the surface rupture on the Sakarya fault segment during the August 17, 1999 İzmit earthquake, Bull. Seism. Soc. Am.

Lindvall, S. C., T. K. Rockwell, and K. W. Hudnut (1989). Evidence for prehistoric earthquakes on the Superstition Hills fault from offset geomorphic features, Seism. Soc. Am. Bull. 79, no. 2, 342-361.

McGill, S. F., and C. M. Rubin (1999). Surficial slip distribution on the central Emerson fault during the June 28, 1992, Landers earthquake, California, J. Geophys. Res. 104, 4811-4833.

McGill, S. F., and K. E. Sieh (1991). Surficial offsets on the central and eastern Garlock fault associated with prehistoric earthquakes, J. Geophys. Res. 96, 21,597-21,621.

Rockwell, T. K., and C. T. Pinault (1986). Holocene slip events on the southern Elsinore fault, Coyote Mountains, southern California, in Guidebook and Volume on Neotectonics and Faulting in Southern California, P. Ehlig (Editor), Cordilleran Section, Geol. Soc. Am. 193-196.

Scientists from the U.S. Geological Survey, Southern California Earthquake Center, and California Division of Mines and Geology (Hector Mine Working Group) (2000). Preliminary report on the 16 October 1999 M 7.1 Hector Mine, California, earthquake, Seism. Res. Lett. 71, no. $1,11-23$.

Sharp, R. V. (1982). Comparison of 1979 surface faulting with earlier displacements in the Imperial Valley, in The Imperial Valley, California, Earthquake of October 15, 1979, U.S. Geol. Surv. Profess. Pap. 1254, 213-222.

Sharp, R. V., K. E. Budding, J. Boatwright, M. J. Ader, M. G. Bonilla, M. M. Clark, T. E. Fumal, K. K. Harms, J. J. Lienkaemper, D. M. Morton, J. O. O’Neill, C. L. Ostergren, D. J. Ponti, M. J. Rymer, J. L. Saxton, and J. D. Sims (1989). Surface faulting along the Superstition Hills fault zone and nearby faults associated with the earthquakes of 24 November 1987, Bull. Seism. Soc. Am. 9, no. 2, 252-281.

Sieh, K. (1978). Slip along the San Andreas fault associated with the great 1857 earthquake, Bull. Seism. Soc. Am. 68, 1421-1448.

Sieh, K., et al. (1993). Near-field investigations of the Landers earthquake sequence, April to July, 1992, Science 260, 171-176.

U.S Geological Survey (2000). Implications for earthquake risk reduction in the United States from the Kocaeli, Turkey, earthquake of August 17, 1999, U.S. Geol. Surv. Circular 1193, 64.

Weldon, R. J., T. K. Rockwell, and J. McCalpin (1996). Strike-slip fault paleoseismic environments, in Paleoseismology, Geophysics Series, J. McCalpin (Editor), Vol. 62, Academic, New York.

Wells, D. L., and K. L. Coppersmith (1994). New empirical relationships among magnitude, rupture length, rupture width, rupture area, and surface displacement, Bull. Seism. Soc. Am. 84, 974-1002. 
Zachariasen, J., and K. Sieh (1995). The transfer of slip between two en echelon strike-slip faults: a case study from the 1992 Landers earthquake, southern California, J. Geophys. Res. 100, 15,281-15,301.

Earth Consultants International, Inc.

2522 N. Santiago Blvd.

Suite B, Orange, California 92867

(T.K.R., T.D.)

William Lettis \& Associates, Inc.

25050 Avenue Kearny

Suite 108

Valencia, California 91355

(S.L.)

U.S. Geological Survey

345 Middlefield Road

MS977

Menlo Park, California 94025

(R.L.)
Institute of Geological and Nuclear Sciences

P.O. Box 30-368

Lower Hut, New Zealand

(R.L.)

William Lettis \& Associates, Inc.

1777 Botelho Drive, Suite 262

Walnut Creek, California 94596

(W.L.)

California Institute of Technology

Pasadena, California 91125

(Y.K.)

Manuscript received 20 August 2001. 